\title{
Karyological Analysis of Endemic Five Muscari Taxa
}

\author{
Meryem Bozkurt* \\ Science Faculty, Department of Biology, Selçuk University, Konya, Turkey
}

Received July 6, 2020; accepted July 20, 2020

\begin{abstract}
Summary Five endemic Muscari taxa in Turkey are examined in terms of chromosome number and morphology. Muscari sivrihisardaghlarense $(2 n=18)$, M. serpentinicum $(2 n=18)$, M. atillae $(2 n=18)$ and M. ufukii $(2 n=18)$ are diploid. M. tuzgoluense is polyploid with $2 n=36$ chromosome number. Chromosome counts have confirmed the previous reports that Muscari genus is $x=9$ of basic chromosome number. The chromosome number and morphology of these species are reported for the first time. The karyotypes have the predominance of metacentric and submetacentric chromosomes. Six quantitative asymmetric indices were used to evaluate the karyological characteristics of the species, and these results increase our karyological knowledge about the species.
\end{abstract}

Keywords Chromosome number, Endemic, Karyomorphology, Karyotype, Muscari, Turkey.

The genus Muscari Miller, which is distributed in Europe, the Mediterranean region, and Southwest Asia, is represented by about 54 species (Jafari and Maassoumi 2011). Some species of the genus are used as ornamental plants in the park and gardens (Ferrauto and Pavone 2016). In Turkey, Muscari is represented by 44 species, of which 31 endemics (Demirci Kayıran et al. 2019, Doğu and Uysal 2019, Eker 2019a, b, Eker et al. 2019, Yıldırımlı and Kılıç 2019). When considering the density of the species number and endemism rate in Muscari, Turkey is one of the main differentiation and gene centers (Y1ldırım 2016, Böhnert and Lobin 2017, Doğu and Uysal 2019). In Muscari, both the taxonomic and the karyological situations are quite complex (Davis and Stuart 1980, 1984, Speta 1989, 1998, Karlén 1991, Azizi et al. 2016). The use of karyological data in the taxonomy can be handled as taxonomic evidence for biosystematics classification at the level of family, genus, and species and even it can contribute to evaluating the genetic relationship among populations belonging to species (Stace 1980, Odah and Oran 2007, Guerra 2008). The main goal of this study is to reveal the karyomorphological features of Turkish endemic Muscari species and trying to explain the effect of chromosomal behaviors on species-related relationships.

Materials and methods

Plant materials belonging to Muscari five taxa were collected from natural areas of Turkey (Table 1). At least three bulbs each taxon studied were germinated in suitably prepared foams in the water. Chromosome

\footnotetext{
* Corresponding author, e-mail: mbozkurt@selcuk.edu.tr DOI: $10.1508 /$ cytologia. 85.289
}

count was performed by the crushing technique (Goldblatt 1996). The root tips from the bulbs were treated with $2 \mathrm{mM}$ 8-hydroxyquinoline at $4^{\circ} \mathrm{C}$ for $8 \mathrm{~h}$. After the pretreatment, the materials were fixed with Carnoy fixative at low temperature for $24 \mathrm{~h}$. For the staining process, the materials were hydrolyzed with $5 \mathrm{M} \mathrm{HCl}$ for $1 \mathrm{~h}$ at room temperature and they were stained with $1 \%$ aceto-orcein. After obtaining the best metaphase, the pictures of the chromosomes were taken with an Olympus DP72 digital camera mounted on an Olympus BX53 microscope. Karyotype measurements were performed with the KAMERAM program (Argenit KAMERAM GEN3) on the best metaphase images obtained and karyomorphology was determined using various symmetry indices. The morphology of chromosomes was named according to Levan et al. (1964). The intrachromosomal asymmetry index $\left(\mathrm{A}_{1}\right)$ and the interchromosomal asymmetry index $\left(\mathrm{A}_{2}\right)$ proposed by Romero Zarco (1986) were used. Karyotype asymmetry was estimated using the coefficient of variation of chromosome length $\left(\mathrm{CV}_{\mathrm{CL}}\right)$, the coefficient of variation of the centromeric index $\left(\mathrm{CV}_{\mathrm{CI}}\right)$, and karyotype asymmetry index (AI) proposed by Paszko (2006). The mean centromeric asymmetry $\left(\mathrm{M}_{\mathrm{CA}}\right)$ was also calculated according to the formula given by Peruzzi and Eroğlu (2013). The karyograms of taxa were made using the KAMERAM program.

$$
\text { Results }
$$

In this study, chromosome number and morphology of five Muscari taxa are given for the first time (Tables 2, 3).

M. sivrihisardaghlarense, which is distributed in Central Anatolia, is a rare endemic species and it has a diploid chromosome number of $2 n=18$ (Figs. 1A, 2A). 
Table 1. Taxa studied and localities.

\begin{tabular}{|c|c|c|}
\hline Subgenus & Taxon & Locality \\
\hline Botryanthus & M. sivrihisardaghlarense & $\begin{array}{l}\text { Sivrihisar-Karacaören, Eryiğit radar station, J. excelse-J. oxycedrus clearings, 1,662 m, } 07 \text { iv } 2018 \text {, } \\
\text { H. Demirelma } 3360 \text { and H. Dural. }\end{array}$ \\
\hline Botryanthus & M. serpentinicum & Muğla, Çamobası, 1,444 m, 02 iv 2018, T. Uysal 3442 and M. Bozkurt. \\
\hline Botryanthus & M. atillae & Malatya, Akçadag, Levent canyon, southeast slopes of Çayözü village, $1,110 \mathrm{~m}, 28$ iv 2018, T. Uysal 3618. \\
\hline Botryanthus & M. tuzgoluense & Konya, Gölyaz1-Eskil road 2 km, halophytic steppe, $950 \mathrm{~m}, 02$ v 2018, T. Uysal 3639. \\
\hline Leopoldia & M. ufukii & $\begin{array}{l}\text { Gaziantep-Osmaniye road, } 38 \mathrm{~km} \text { from Gaziantep, oak-Pistacia formation clearings to the right of } \\
\text { the road, 1,096-1,115 m, } 04 \text { vi 2018, T. Uysal } 3728 \text { and M. Bozkurt. }\end{array}$ \\
\hline
\end{tabular}

Table 2. The chromosome features of Muscari taxa.

\begin{tabular}{|c|c|c|c|c|c|c|c|c|c|}
\hline Taxa & $2 n$ & $\begin{array}{c}\text { SC-LC } \\
(\mu \mathrm{m})\end{array}$ & $\mathrm{LC} / \mathrm{SC}$ & $\begin{array}{c}\mathrm{p}(\mu \mathrm{m}) \\
( \pm \mathrm{SD})\end{array}$ & $\begin{array}{l}\mathrm{q}(\mu \mathrm{m}) \\
( \pm \mathrm{SD})\end{array}$ & $\begin{array}{c}\mathrm{CL}(\mu \mathrm{m}) \\
( \pm \mathrm{SD})\end{array}$ & $\begin{array}{l}\text { TCL } \\
(\mu \mathrm{m})\end{array}$ & $\begin{array}{c}\text { CI } \\
( \pm \mathrm{SD})\end{array}$ & $\mathrm{KF}$ \\
\hline M. sivrihisardaghlarense & 18 & $1.22-2.31$ & 1.903 & $0.72( \pm 0.09)$ & $0.93( \pm 0.27)$ & $1.65( \pm 0.35)$ & 14.846 & $44( \pm 0.04)$ & $16 \mathrm{~m}+2 \mathrm{sm}$ \\
\hline M. serpentinicum & 18 & $1.15-3.22$ & 2.797 & $0.70( \pm 0.14)$ & $1.13( \pm 0.64)$ & $1.83( \pm 0.73)$ & 16.469 & $42( \pm 0.09)$ & $14 m+2 s m+2 s t$ \\
\hline M. atillae & 18 & $1.13-3.14$ & 2.771 & $0.73( \pm 0.19)$ & $1.17( \pm 0.52)$ & $1.89( \pm 0.69)$ & 17.013 & $40( \pm 0.06)$ & $12 \mathrm{~m}+6 \mathrm{sm}$ \\
\hline M. tuzgoluense & 36 & $0.99-1.83$ & 1.856 & $0.61( \pm 0.11)$ & $0.80( \pm 0.19)$ & $1.41( \pm 0.29)$ & 25.44 & $44( \pm 0.03)$ & $32 \mathrm{~m}+4 \mathrm{sm}$ \\
\hline M. ufukii & 18 & $1.58-4.77$ & 3.01 & $1.01( \pm 0.24)$ & $1.85( \pm 0.94)$ & $2.86( \pm 1.14)$ & 25.729 & $38( \pm 0.08)$ & $10 m+6 s m+2 s t$ \\
\hline
\end{tabular}

SC: Shortest chromosome length, LC: longest chromosome length, p: mean length of the long and short arm, q: mean length of the long arm, CL: mean chromosome length, TCL: total haploid chromosome length, CI: mean centromeric index, SD: standard deviation, KF: karyotype formula, m: metacentric, sm: submetacentric, st: subtelocentric.

Table 3. The karyotype indices of Muscari taxa.

\begin{tabular}{lcccrrr}
\hline \multicolumn{1}{c}{ Taxa } & $\mathrm{A}_{1}$ & $\mathrm{~A}_{2}$ & $\mathrm{CV}_{\mathrm{CL}}$ & $\mathrm{CV}_{\mathrm{CI}}$ & $\mathrm{AI}$ & $\mathrm{M}_{\mathrm{CA}}$ \\
\hline M. sivrihisardaghlarense & 0.191 & 0.213 & 21.258 & 9.913 & 2.107 \\
M. serpentinicum & 0.258 & 0.398 & 39.826 & 20.552 & 8.185 \\
M. atillae & 0.325 & 0.366 & 36.609 & 14.349 & 23.49 \\
M. tuzgoluense & 0.215 & 0.205 & 20.517 & 7.722 & 1.584 \\
M. ufukii & 0.356 & 0.399 & 39.896 & 20.421 & 8.147 \\
\hline
\end{tabular}

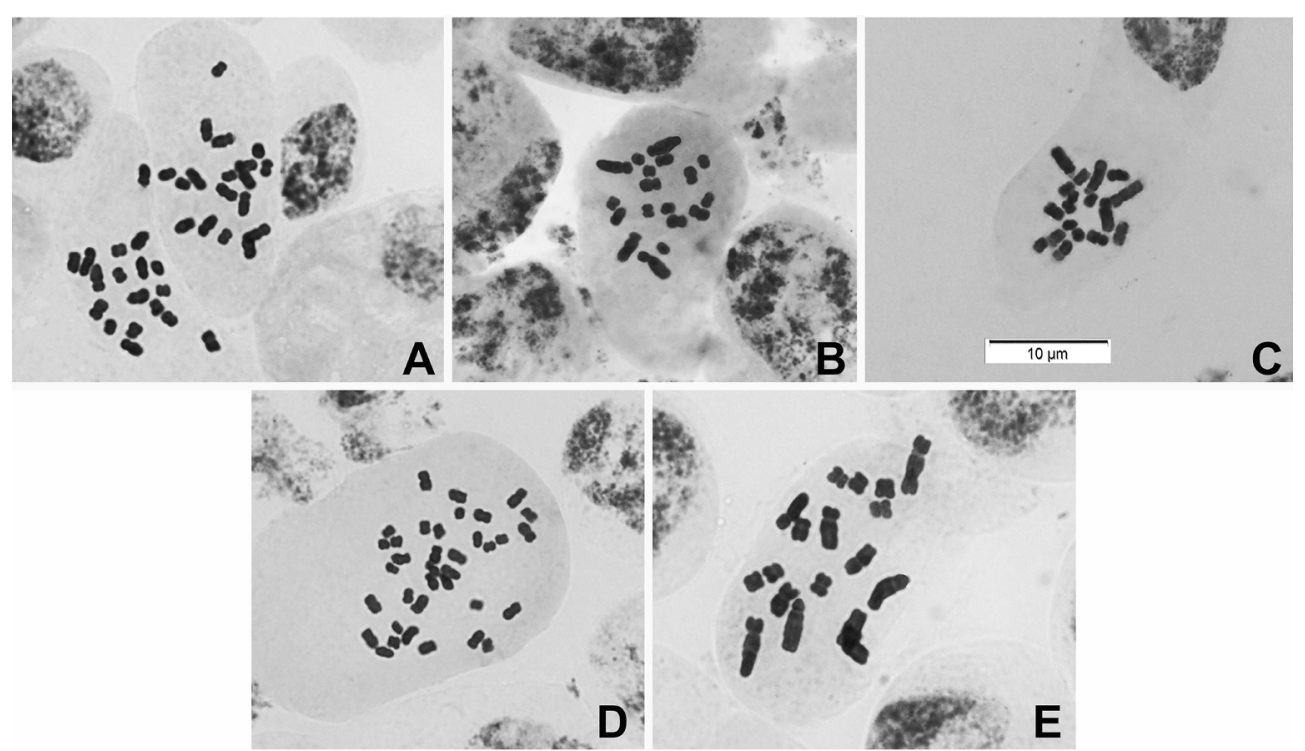

Fig. 1. Mitotic metaphase chromosomes of Muscari taxa. A: M. sivrihisardaghlarense, B: M. serpentinicum, C: M. atillae, D: M. tuzgoluense, E: M. ufukii.

The chromosome number and morphology of this species was determined for the first time. The karyotype formula (KF: $16 \mathrm{~m}+2 \mathrm{sm}$ ), coefficient of variation of chromosome length $\left(\mathrm{CV}_{\mathrm{CL}}: 21.258\right)$, and coefficient of variation of the centromeric index $\left(\mathrm{CV}_{\mathrm{CI}}: 9.913\right)$ of this species were given in Tables 1 and 2 .
M. serpentinicum, which is known from a single locality in the Sandras mountain in Muğla (southwestern Anatolia region of Turkey), is a local endemic species and it has a diploid chromosome number of $2 n=18$ (Figs. 1B, 2B). The chromosome number and morphology of this species was determined for the first time. KF 


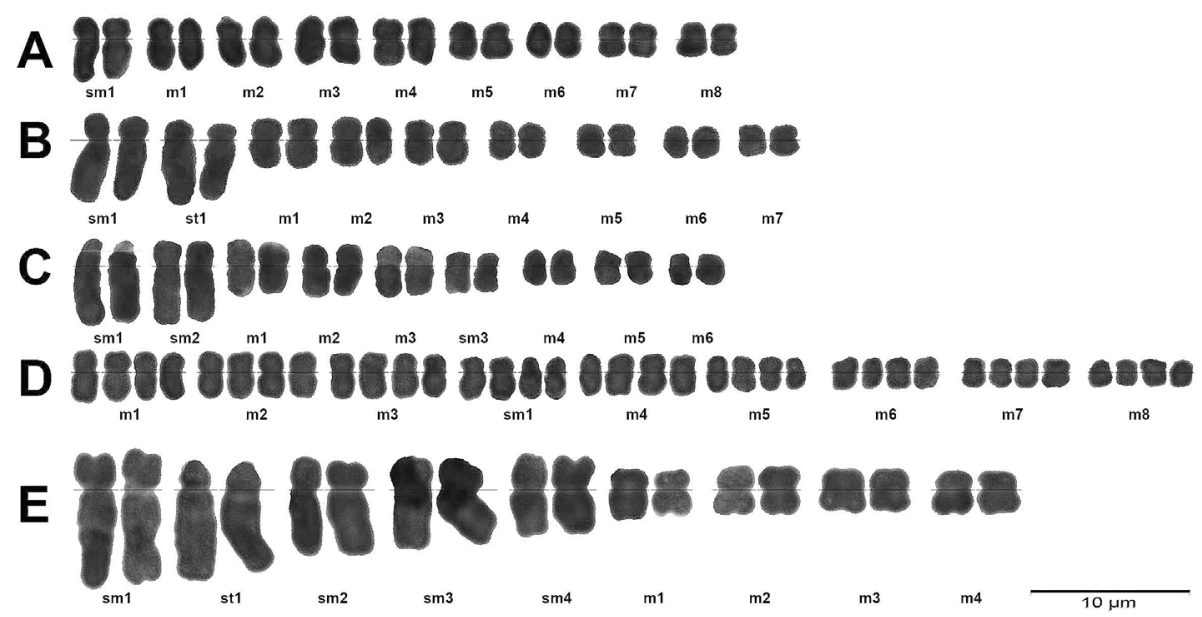

Fig. 2. Karyograms of Muscari taxa. A: M. sivrihisardaghlarense, B: M. serpentinicum, C: M. atillae, D: M. tuzgoluense, E: M. ufukii.

$(14 m+2 s m+2 s t), \mathrm{CV}_{\mathrm{CL}}$ (39.826), and $\mathrm{CV}_{\mathrm{CI}}$ (20.552) of this species were given in Tables 1 and 2 .

M. atillae, which is known from a restricted area in Levent Canyon in Malatya (eastern Anatolia region of Turkey), is an endemic species and it has a diploid chromosome number of $2 n=18$ (Figs. 1C, 2C). The satellite was detected in the first chromosome pair of this species. The chromosome number and morphology of this species was determined for the first time. KF $(12 \mathrm{~m}+6 \mathrm{sm}), \mathrm{CV}_{\mathrm{CL}}$ (36.609), and $\mathrm{CV}_{\mathrm{CI}}$ (14.349) of this species were given in Tables 1 and 2 .

M. tuzgoluense grown in extreme environmental conditions is an endemic species and it has a polyploid chromosome number of $2 n=36$ (Figs. 1D, 2D). The chromosome number and morphology of this species was determined for the first time. $\mathrm{KF}(32 \mathrm{~m}+4 \mathrm{sm}), \mathrm{CV}_{\mathrm{CL}}$ (20.517) and $\mathrm{CV}_{\mathrm{CI}}$ (7.722) of this species were given in Tables 1 and 2.

M. ufukii is an endemic species and it has a diploid chromosome number of $2 n=18$ (Figs. 1E, 2E). The chromosome number and morphology of this species was determined for the first time. $\mathrm{KF}(10 \mathrm{~m}+6 \mathrm{sm}+2 \mathrm{st}), \mathrm{CV}_{\mathrm{CL}}$ (39.896), and $\mathrm{CV}_{\mathrm{CI}}$ (20.421) of this species were given in Tables 1 and 2.

\section{Discussion}

Karyological studies for the Muscari have shown that the main evolutionary mechanisms involving chromosome rearrangement and polyploidy are effective in the diversification of the genus (Bentzer 1969, 1972, 1974, Bentzer and Ellmer 1975, Oliver and Ruiz-Rejón 1980, Ruiz-Rejón et al. 1985, Valdés and Díaz-Lifante 1992, Cuñado et al. 2000, De la Herrán et al. 2001). Therefore, the last taxonomic arrangements of the Muscari are based on karyological data (Garbari 1968, 1969, Demirci et al. 2013, Doğu and Uysal 2019, Eroğlu and Pınar 2019). Also, the recently described new species were determined the karyological features (Demirci et al. 2013,
Demirci Kayıran et al. 2019, Doğu and Uysal 2019, Eroğlu and Pınar 2019).

In this study, five species are diploid $(2 n=18)$ except for M. tuzgoluense, which is tetraploid $(2 n=36)$. The karyotypes of $M$. sivrihisardaghlarense, $M$. serpentinicum, M. atillae, M. tuzgoluense and M. ufukii are different from each other $(16 \mathrm{~m}+2 \mathrm{sm}, 14 \mathrm{~m}+2 \mathrm{sm}+2 \mathrm{st}$, $12 m+6 s m, 32 m+4 s m$, and $10 m+6 s m+2 s t$, respectively) and mostly consist of metacentric chromosomes.

Ylldırıml and Selvi (2002) reported that M. sivrihisardaghlarense is morphologically closely related to the species M. armeniacum and M. neglectum, but differ in terms of characteristics such as shorter and reddish scape, linear leaves, and shorter raceme. Besides the morphological differences, karyotypes of this endemic species (Table 2) are quite distinct from M. armeniacum and M. neglectum reported (Table 4; Karlén 1984, Jafari et al. 2008, Demirci Kayıran and Özhatay 2017).

Pirhan et al. (2014) reported that M. serpentinicum related to M. commutatum and M. latifolium. In previous karyotypes of $M$. commutatum and M. latifolium; in the idiogram of M. commutatum, Karlén (1984) determined that the five long $\mathrm{m}$ to sm pairs decrease more or less continuously in length from the first to the fifth and, the four short pairs are $\mathrm{m}$. He determined that the satellites are situated on the short arms of the second pair. Stuart (1970) found that M. latifolium has its satellites on the long arms of the second pair. Moreover, Stuart (1966) reported that the karyotypes of $M$. latifolium and $M$. bourgaei are also very much like the Leopoldia (Parl.) Rouy. In the karyotype of the M. serpentinicum, there are metacentric and submetacentric chromosomes as well as subtelocentric chromosomes. In addition, there is no satellite in the chromosomes of the M. serpentinicum. However, the karyotypes of $M$. commutatum and $M$. latifolium are placed on satellites (Stuart 1970, Karlén 1984).

Ylldırım (2015) reported that $M$. atillae has similarities with $M$. discolor and M. anatolicum in terms of 
Table 4. Comparison of the results with the previously reported karyotype formulas for Muscari taxa.

\begin{tabular}{|c|c|c|}
\hline Taxa & Karyotype formula & References \\
\hline M. sivrihisardaghlarense & $16 \mathrm{~m}+2 \mathrm{sm}$ (diploid) & in this study \\
\hline \multirow[t]{7}{*}{ M. neglectum } & $4 \mathrm{~m}+10 \mathrm{sm}+4 \mathrm{st}^{\mathrm{SAT}}$ (diploid) & Demirci Kayıran and Özhatay (2017) \\
\hline & $16 \mathrm{~m}+12 \mathrm{sm}+8 \mathrm{st}$ (tetraploid) & Demirci Kayıran and Özhatay (2017) \\
\hline & $35 \mathrm{~m}+\mathrm{m}^{\mathrm{SAT}}+18 \mathrm{sm}, 36 \mathrm{~m}+18 \mathrm{sm}$ (hexaploid) & Demirci Kayıran and Özhatay (2017) \\
\hline & $n=4 \mathrm{~m}+5 \mathrm{sm}$ (diploid, tetraploid, hexaploid, oktaploid) & Karlén 1984 \\
\hline & $\begin{array}{c}13 \mathrm{~m}+11 \mathrm{sm}+2 \mathrm{st}+\mathrm{t}, 23 \mathrm{~m}+3 \mathrm{sm}, 21 \mathrm{~m}+5 \mathrm{sm}, 16 \mathrm{~m}+9 \mathrm{sm}+\mathrm{t} \text { or } \\
16 \mathrm{~m}+7 \mathrm{sm}, 13 \mathrm{~m}+9 \mathrm{sm}+\mathrm{st}, 17 \mathrm{~m}+5 \mathrm{sm}+\mathrm{st} \text { (aneuploid) }\end{array}$ & Jafari et al. (2008) \\
\hline & $17 \mathrm{~m}+5 \mathrm{sm}+\mathrm{st}$ (autopentaploid) & Jafari et al. (2008) \\
\hline & $14 \mathrm{~m}+3 \mathrm{sm}$ (tetraploid) & Jafari et al. (2008) \\
\hline \multirow[t]{2}{*}{ M. armeniacum } & $12 \mathrm{~m}+4 \mathrm{sm}+2 \mathrm{st}^{\mathrm{SAT}}, 12 \mathrm{~m}+4 \mathrm{sm}+2 \mathrm{st}$ & Demirci Kayıran and Özhatay (2017) \\
\hline & $n=7 \mathrm{~m}+2 \mathrm{sm}$ & Karlén 1984 \\
\hline
\end{tabular}

some morphological features. Arslan and Uysal (2009) reported that there are five $\mathrm{m}$ and four sm pairs in the karyotype of the $M$. discolor. They also reported that satellite was placed in the long arm of the 6th chromosome pair of this species. Demirci Kayıran and Özhatay (2017) reported the karyotype of $M$. anatolicum as $2 n=3 x=27=15 \mathrm{~m}+9 \mathrm{sm}+3 \mathrm{st}$ (triploid). We can say that M. atillae differs from $M$. discolor and M. anatolicum in terms of chromosome morphology as well as general morphological aspect.

Demirci et al. (2014) reported that M. ufukii is close to M. longipes and M. tenuiflorum. Jafari et al. (2008) determined the karyotype formula of $M$. longipes as $2 \mathrm{~m}+4 \mathrm{sm}+3 \mathrm{st}$. The previous karyotypes of M. tenuiflorum were reported as $2 n=18=8 \mathrm{~m}+6 \mathrm{sm}+4 \mathrm{st}$ (Demirci Kayıran and Özhatay 2017), $5 \mathrm{~m}+3 \mathrm{sm}+1 \mathrm{st}$ or $1 \mathrm{~m}+5 \mathrm{sm}+6 \mathrm{st}+1 \mathrm{t}$ (Jafari et al. 2008), and $2 \mathrm{st}+2 \mathrm{sm}+14 \mathrm{~m}$ (Doğu and Uysal 2019). The TCL of the M. ufukii, which is a member of the Leopoldia, is larger than the Botryanthus taxa (Table 2). These findings are consistent with previous reports (Stuart 1970, Jafari et al. 2008). According to Lima De Faria (1980), chromosomes are uniform in size; in all studied Muscari taxa having small chromosomes (CL: 1.41-2.91 $\mu \mathrm{m}$ ). The chromosome lengths for some taxa of the Muscari (CL: $1.08-5.78 \mu \mathrm{m})$ are notified as small and medium-size and these sizes (Demirci Kayıran and Özhatay 2017) are largely consistent with our results. The TCL of the M. sivrihisardaghlarense, M. serpentinicum, M. atillae, M. tuzgoluense is compatible with the values (16-37 $\mu \mathrm{m})$ previously reported in the Botryanthus (Kunth) Rouy (Demirci Kayıran and Özhatay 2017).

Polyploidy in plants has been identified as one of the main processes that cause genetic diversity and speciation (Stebbins 1950, Grant 1971, Rieseberg 1997, Wendel 2000, Doyle et al. 2003). Garbari (1972) claimed that the Bellevalia with $x=4$ basic chromosome number had the potential ancestor of the Muscari as a result of its polyploidy and aneuploidy. In Muscari, polyploidy is more common in Botryanthus (such as M. parviflorum $2 n=36$; Rossi and Capineri 1982, Speta 1982, Garbari 1984, Demirci Kayıran and Özhatay 2017). In addition, many species in this subgenus (such as $M$. neglectum species) have been reported to have ploidy levels (Davis and Stuart 1984, Karlén 1984, Valdés and Mejías 1988, Karlén 1991, Valdés 1996, Garbari 2003). A new polyploid species, M. tuzgoluense, for the Botryanthus was reported for the first time in this study.

According to Stebbins (1971), an increase in intrachromosomal asymmetry occurs due to the change in the centromeric position of the chromosomes and symmetrical karyotype composed of $\mathrm{m}$ and $\mathrm{sm}$ is primitive. We can say that $M$. sivrihisardaghlarense and $M$. tuzgoluense, which have the most symmetrical karyotypes, are primitive among five species studied. As a result of the analyses, the change in the centromeric position of the chromosomes and high $\mathrm{CV}_{\mathrm{CI}}$ showed that the chromosomal heterogeneity of $M$. serpentinicum and M. ufukii is high. Another parameter used to measure intrachromosomal asymmetry is $\mathrm{M}_{\mathrm{CA}}$. The presence of symmetric and asymmetric karyotypes implies chromosomal rearrangements and different evolutionary steps (Uysal et al. 2017). Among the studied species, M. ufukii $\left(\mathrm{CV}_{\mathrm{CL}}: 39.896, \mathrm{AI}: 8.147, \mathrm{M}_{\mathrm{CA}}: 29.37\right)$ has the most asymmetric karyotypes and more advanced in terms of phylogeny and evolutionary process according to Stebbins (1971).

\section{Acknowledgements}

I would like to thanks a lot the foundation Tubitak (project number 117Z222) because of its financial support. I thanks Prof. Dr. Tuna UYSAL, Prof. Dr. Huseyin DURAL and Asst. Prof. Dr. Hakki DEMIRELMA for plant collecting and species identification and I would also like to thanks Prof. Dr. Tuna UYSAL for many valuable suggestions that greatly improved the manuscript.

\section{References}

Arslan, E. and Uysal, T. 2009. A Karyological study on Endemic Muscari discolor Boiss \& Hausskn Species. Selçuk Üniversitesi Fen Edebiyat Fakültesi Fen Dergisi 34: 63-68. (in Turkish)

Azizi, N., Amirouche, R. and Amirouche, N. 2016. Karyological investigations and new chromosome number reports in Bellevalia Lapeyrouse, 1808 and Muscari Miller, 1758 (Asparagaceae) 
from Algeria. Comp. Cytogenet. 10: 171-187.

Bentzer, B. 1969. Chromosome morphology in Aegean populations of Leopoldia Parl. (Liliaceae). Bot. Not. 122: 457-480.

Bentzer, B. 1972. Variation in the chromosome complement of Leopoldia comosa (L.) Parl. (Liliaceae) in the Aegean (Greece). Bot. Not. 125: 406-418.

Bentzer, B. 1974. Karyotypes and meiosis in Leopoldia Parl (Liliaceae) from the southern and central Aegean (Greece). Bot. Not. 127: $69-86$

Bentzer, B. and Ellmer, M. 1975. A case of stable chromosomal polymorphism in Leopoldia comosa (Liliaceae). Hereditas 81: $127-132$.

Böhnert, T. and Lobin, W. 2017. Leopoldia neumannii sp. nov. (Asparagaceae, Scilloideae): A new species of Muscari sensu lato from Greece. Willdenowia 47: 179-185.

Cuñado, N., De la Herrán, R., Santos, J. L., Ruiz-Rejón, C., GarridoRamos, M. A. and Ruiz-Rejón, M. 2000. The evolution of the ribosomal loci in the subgenus Leopoldia of the genus Muscari (Hyacinthaceae). Plant Syst. Evol. 221: 245-252.

Davis, P. H. and Stuart, D. C. 1980. Muscari Mill. In: Tutin, T. G., Heywood, V. H. and Valentine, D. H. (eds.). Flora Europaea Vol. 5. Cambridge University Press, London. pp. 46-49.

Davis, P. H. and Stuart, D. C. 1984. Muscari Mill. In: Davis, P. H. (ed.). Flora of Turkey and the East Aegean Islands 8. Edinburgh University Press, Edinburgh. pp. 245-263.

De la Herrán, R., Robles, F., Cuñado, N., Santos, J. L., Ruiz-Rejón, M., Garrido-Ramos, M. A. and Ruiz-Rejón, C. 2001. A heterochromatic satellite DNA is highly amplified in a single chromosome of Muscari (Hyacinthaceae). Chromosoma 110: 197-202.

Demirci Kayıran, S. and Özhatay, F. N. 2017. A karyomorphological study on the genus Muscari Mill. growing in Kahramanmaraş (Turkey). Turk. J. Bot. 41: 289-298.

Demirci Kayıran, S., Özhatay, N. and Kaya, E. 2019. Muscari tauricum (Asparagaceae, Scilloideae), a new species from Turkey. Phytotaxa 399: 109-118.

Demirci, S., Özhatay, N., Gürdal, B. and Kaya, E. 2014. Contributions to the Turkish Geophyte Flora. In: Kaya, E. (ed.). Muscari Mill. Geophytes of Turkey 3. Atatürk Central Horticultural Research Institute, Edition No: 96, Yalova, pp. 543-550. (in Turkish)

Demirci, S., Özhatay, N. and Koçyiğit, M. 2013. Muscari erdalii (Asparagaceae, Scilloideae), a new species from Southern Turkey. Phytotaxa 154: 38-46.

Doğu, S. and Uysal, T. 2019. Muscari savranii (Asparagaceae), a new species from central Anatolia, Turkey. Phytotaxa 402: 155-164.

Doyle, J. J., Doyle, J. L., Rauscher, J. T. and Brown, A. H. D. 2003. Diploid and polyploid reticulate evolution throughout the history of the perennial soybeans (Glycine subgenus Glycine). New Phytol. 161: 121-132.

Eker, İ. 2019a. Muscari fatmacereniae (Asparagaceae, Scilloideae), a new species from southern Anatolia. Phytotaxa 397: 99-106.

Eker, İ. 2019b. Muscari pamiryigidii (Asparagaceae, Scilloideae), a new species from northwestern Anatolia. Phytotaxa 408: 255-266.

Eker, İ., Yıldırım, H. and Armağan, M. 2019. A new grape hyacinth record for the flora of Turkey: Muscari pallens (M. Bieb.) Fisch. (Asparagaceae). Bağbahçe Bilim Dergisi 6: 45-53. (in Turkish)

Eroğlu, H. and Pınar, S. M. 2019. The taxonomic resurrection of Muscari haradjianii (Asparagaceae, Scilloideae), and a new synonym in the genus Muscari in Turkey. Phytotaxa 418: 97-106.

Ferrauto, G. and Pavone, P. 2016. Pollen morphology and taxonomic implications of Muscari Miller (Hyacinthaceae) species from Sicily. Plant Biosyst. 150: 27-34

Garbari, F. 1968. The Muscari genus (Liliaceae): Contribution to the cytotaxonomic review. Giorn. Bot. Ital. 102: 87-105. (in Italian)

Garbari, F. 1969. New cytological observations on the Muscari and Leopoldia genera. Giorn. Bot. Ital. 103: 1-9. (in Italian)
Garbari, F. 1972. Notes on the genus Pseudomuscari (Liliaceae). Webbia 27: 369-381. (in Italian)

Garbari, F. 1984. Some karyological and taxonomic remarks on the Italian Muscari (Liliaceae). Webbia 38: 139-164.

Garbari, F. 2003. Muscari neglectum Guss. and M. atlanticum Boiss. et Reuter (Hyacinthaceae). Types, characters and comments on the two species. Inform. Bot. Ital. 35: 329-336. (in Italian)

Goldblatt, P. 1996. Index to Plant Chromosome Numbers 1992-1993. Monographs in Systematic Botany from the Missouri Botanical Garden 58: 1-276.

Grant, V. 1971. Plant Speciation. Columbia University Press, New York.

Guerra, M. 2008. Chromosome numbers in plant cytotaxonomy: Concepts and implications. Cytogenet. Genome Res. 120: 339-350.

Jafari, A. and Maassoumi, A. A. 2011. Synopsis of Leopoldia, Muscari and Pseudomuscari (Hyacithaceae) in Iran, with Leopoldia ghouschtchiensis sp. nova. Ann. Bot. Fenn. 48: 396-400.

Jafari, A., Maassoumi, A. A. and Farsi, M. 2008. Karyological study on Bellevalia and Muscari (Liliaceae) species of Iran. Asian J. Plant Sci. 7: 50-59.

Karlén, T. 1984. Karyotypes and chromosome numbers of five species of Muscari (Liliaceae). Willdenowia 14: 313-320.

Karlén, T. 1991. Muscari Miller. In: Strid, A. and Tan, K. (eds.). Mountain Flora of Greece Vol. 2. Edinburgh University Press, Edinburgh. pp. 697-701.

Levan, A., Fredga, K. and Sandberg, A. A. 1964. Nomenclature for centromeric position on chromosomes. Hereditas 52: 201-220.

Lima De Faria, A. 1980. Classification of genes, rearrangements and chromosomes according to the chromosome field. Hereditas 93: $1-46$.

Odah, M. and Oran, S. 2007. Karyological study of the genus Ornithogalum (Lilliaceae) in Jordan, dirasat. Pure Sci. 34: 210-220.

Oliver, J. L. and Ruiz-Rejón, M. 1980. The relation between isozymes and ploidy level. Its application to biogeographical studies of Muscari atlanticum (Liliaceae). Taxon 29: 27-32.

Paszko, B. 2006. A critical review and a new proposal of karyotype asymmetry indices. Plant Syst. Evol. 258: 39-48.

Peruzzi, L. and Eroğlu, H. E. 2013. Karyotype asymmetry: Again, how to measure and what to measure? Comp. Cytogenet. 7: 1-9.

Pirhan, A. F., Yıldırım, H. and Altığlu, Y. 2014. Muscari serpentinicum sp. nova (Asparagaceae): A new species from western Anatolia, Turkey. Ot Sist. Bot. Dergisi 21: 1-14.

Rieseberg, L. H. 1997. Hybrid origins of plant species. Annu. Rev. Ecol. Syst. 28: 359-389.

Romero-Zarco, C. 1986. A new method for estimating karyotype asymmetry. Taxon 35: 526-530.

Rossi, W. and Capineri, R. 1982. Observations on Muscari parviflorum Desf. in Italy. Ann. Bot. 40: 107-110. (in Italian)

Ruiz-Rejón, M., Pascual, L., Ruiz-Rejón, C., Valdés, B. and Oliver, J. L. 1985. A new species of Muscari subgenus Leopoldia from the Iberian peninsula. Biochem. Syst. Ecol. 13: 239-250.

Stace, C. A. 1980. Plant Taxonomy and Biosystematics. Edward Arnold, London.

Speta, F. 1982. Über die Abgrenzung und Gliederung der Gattung Muscari und über ihre Beziehungen zu anderen Vertretern der Hyacinthaceae. Bot. Jahrb Syst. 103: 247-291.

Speta, F. 1989. Muscari (subg. Leopoldia) mirum Speta, spec. nova, im kreise seiner nachsten verwandten. Phyton (Horn) 29: 105-114.

Speta, F. 1998. Hyacithaceae. In: Kubitzki, K. (ed.). The Families and Genera of Vascular Plants, 3. Monocotyledons. Springer Verlag, Heidelberg. pp. 261-285.

Stebbins, G. L. 1950. Variation and Evolution in Plants. Columbia University Press, New York.

Stebbins, G. L. 1971. Chromosomal Evolution in Higher Plants. Edward Arnold, London. 
Stuart, D. C. 1966. Cytotaxonomic studies in Muscari sensu lato. Thesis University of Edinburgh, Edinburgh.

Stuart, D. C. 1970. Chromosome numbers in the genus Muscari. Notes R. Bot. Gard. Edinb. 30: 189-196.

Uysal, T., Bozkurt, M., Tugay, O., Ertuğrul, K., Şimşek Sezer, E. N. and Köse, Y. B. 2017. Karyomorphology of Turkish species in Centaurea sections Centaurea and Phalolepis (Asteraceae) and implications for taxonomy. Plant Biosyst. 151: 949-964.

Valdés, B. 1996. Notas sobre Liliáceas del N de Marruecos. Lagascalia 18: $324-330$.

Valdés, B. and Díaz-Lifante, Z. 1992. Karyology and reproductive biology of Muscari matritensis M. Ruíz Rejón \& al. (Liliaceae). Bot. J. Linn. Soc. 109: 125-130.

Valdés, B. and Mejías, J. A. 1988. Contribución al estudio de la bi- ología de la reproducción de las especies españolas de Muscari (Liliaceae). Lagascalia 15: 95-103.

Wendel, J. F. 2000. Genome evolution in polyploids. Plant Mol. Biol. 42: $225-249$.

Yıldırım, H. 2015. Muscari atillae sp. nova (Asparagaceae): A new species from eastern Anatolia, Turkey. Phytotaxa 213: 291-295.

Y1ldırım, H. 2016. Muscari elmasii sp. nova (Asparagaceae): A new species from western Anatolia, Turkey. Turk. J. Bot. 40: 380-387.

Yıldırımlı, Ş. and Kılıç, Ö. 2019. A new species of Muscari Mill. (Asparagaceae/Liliaceae), M. nazimiyensis from Tunceli, Turkey. Ot Sist. Bot. Dergisi 26: 13-16.

Yildırıml1, S. and Selvi, B. 2002. A new species, Muscari sivrihisardaghlarensis (Liliaceae) from Central Anatolia. Ot Sist. Bot. Dergisi 9: 7-12. 